\title{
Business group affiliation and entrepreneurial orientation: Contingent effect of level of internationalization and firm's performance
}

\author{
Anish Purkayastha ${ }^{1}$ (D) Vishal K. Gupta ${ }^{2}$
}

Accepted: 7 February 2022 / Published online: 22 February 2022

(c) The Author(s) 2022

\begin{abstract}
This paper explores effect of business group affiliation on entrepreneurial orientation of the affiliated firms. Building on the argument that organizational and governance structure influence entrepreneurship, we argue that despite some potential advantage that business group affiliation has on a firm through intermediate market filling roles, the entrenchment behavior of business groups discourages entrepreneurial orientation of affiliated firms. Taking a firm-specific contingent perspective we also posit that the level of internationalization of a firm and its performance helps to alleviate- even counter-the negative influence of business group affiliation on the firm's entrepreneurial orientation. We find support for our predictions in a longitudinal data set of 419 Indian firms for the period from 2006 to 2019. The implications and directions for future research are discussed in the context of business group affiliation in emerging economies.
\end{abstract}

Keywords Business groups · Entrepreneurial orientation · Structure · Institution · Emerging economies

Business group is a collection of firms bound together by formal and informal ties under a common corporate umbrella (Khanna \& Rivkin, 2001). With operations across a wide range of industries with significant scale, business group affiliated firms contribute substantially to the domestic economic activity in many emerging

Anish Purkayastha

anish.purkayastha@sydney.edu.au

Vishal K. Gupta

vkgupta@cba.ua.edu

1 The University of Sydney Business School, The University of Sydney, Sydney NSW 2006, Australia

2 College of Commerce and Business Administration, The University of Alabama, Tuscaloosa, AL 35487, USA 
economies (Colpan, Hikino, \& Lincoln, 2010). For example, the ten largest business groups in India accounted for 23.1 percent of the combined market capitalization of all listed companies in 2017 (Kant, 2017) and the share of the four largest Chaebols in the Korean stock market was 47.42 percent (Yung Sil, 2017). Business groups expand into international markets as well. To illustrate, Indian business group Mahindra has gradually enlarged its international footprint into different parts of the world, including expanding to the USA where it now operates a 'stable' of businesses such as tractors, informational technology and software, and motorized vehicles, among others (Stoll, 2015). Similarly, Charoen Pokphand (a business group from Thailand) has over 200 subsidiaries operating in 20 countries, lists on 7 stock markets, and employs over 100,000 people (Wailerdsak \& Suehiro, 2010).

There is considerable debate on the role of organizational and governance structure in inspiring entrepreneurship in firms (Ahuja \& Morris Lampert, 2001; Covin \& Slevin, 1991). Prior research advises that entrepreneurial orientation (EO), defined as "the simultaneous exhibition of innovativeness, proactiveness, and risk taking" (Stam \& Elfring, 2008: 98), is a desired entrepreneurial behavior for the firms that operate in the face of intense competition as it leads to superior organizational outcome (Covin \& Miles, 2006). After almost three decades of scholarly inquiry, there is consensus that EO captures the recurring entrepreneurial posture of existing firms (Covin \& Slevin, 1991). EO is especially relevant in the context of business group affiliated firms in emerging economies as their operating environment is undergoing institutional transformation due to the firms' adoption of market-based systems (Ramaswamy, Purkayastha, \& Petitt, 2017) and these firms are facing increasing levels of competition from foreign multinationals at their home market (Stucchi, Pedersen, \& Kumar, 2015) as well.

There are two parallel but opposite views on the implications of business group affiliation on entrepreneurial behaviors of a firm. On the one hand, proponents of institutional voids view business groups as a structural response to underdeveloped institutions in emerging economies (Gopal, Manikandan, \& Ramachandran, 2021). This perspective supports the view that uniqueness of the organizational and governance structure of a business group adds value to the affiliated firms through efficient market intermediation functions (Belenzon \& Berkovitz, 2010). In contrast, the entrenchment view states that business group affiliation creates principal-principal agency cost through pyramidal structures and opaque governance (Bertrand, Mehta, \& Mullainathan, 2002; Purkayastha, Pattnaik, \& Pathak, 2021b). A business group setup facilitates increasing level of related party transactions within the group (Jia, Shi, \& Wang, 2013; Nakajima \& Sasaki, 2020) which leads to transfer of profits from minority shareholders to controlling stakeholders instead of investing into innovation or building risk-taking capability (Masulis, Pham, \& Zein, 2011; Morck, Wolfenzon, \& Yeung, 2005). To advance this debate between facilitating and detrimental entrepreneurial possibilities associated with structural and governance uniqueness of the business group, we seek to answer a specific question about the strategic implications of group affiliation (Carney, Van Essen, Estrin, \& Shapiro, 2018; Holmes, Hoskisson, Kim, Wan, \& Holcomb, 2018; Mukherjee, Makarius, \& Stevens, 2018): "How does business group affiliation influence the entrepreneurial orientation of the affiliated firm compared to another un-affiliated firm?". 
We also investigate two firm-specific contingent factors that influence the EO of business group affiliated firm compared to an un-affiliated firm (Kostova, Roth, \& Dacin, 2008; Kumar, Singh, Purkayastha, Popli, \& Gaur, 2020). These factors are relevant to the organizational and governance characteristics of emerging economies. First, other than risk-reduction through economy of scale and scope (Peng \& Delios, 2006; Rugman, 1976), the level of international expansion of a firm also increases the learning opportunities (Purkayastha, Kumar, \& Gupta, 2021a) for these emerging economy firms and leads to greater innovation performance (Piperopoulos, Wu, \& Wang, 2018). Though firms from emerging economies have expanded significantly into international markets (Chittoor \& Aulakh, 2015; Mukherjee, Makarius, \& Stevens, 2021), the entrepreneurial implications of internationalization of these firms, in conjunction with group affiliation, has largely been unexplored (Lamin, 2006; Peng, Wang, \& Jiang, 2008; Shin, Mendoza, \& Choi, 2021). Second, the domestic competitive environment of emerging economies is also undergoing significant changes with transition into competition driven market (Pedersen \& Stucchi, 2014). In the face of increasing domestic competition and perceived pressure from foreign competitors, emerging economy firms adopt imitative innovation (Nuruzzaman, Singh, \& Pattnaik, 2019). But what remains unclear is the entrepreneurial implication of group level resource-sharing mechanism for economically low performing affiliated firms. We test the hypothesized relationships with the help of a longitudinal data set of 419 Indian business group affiliated and un-affiliated firms from NIFTY 500 index over the fourteen-year period from 2006 to 2019. ${ }^{1}$

Our inquiry seeks to make a number of contributions to the business group literature in the context of emerging economy (Li \& Yayavaram, 2021; Mukherjee et al., 2018). First, although business groups may be an answer to 'institutional voids' (Khanna \& Palepu, 1997; Kim \& Song, 2017) and group affiliation may complement institutional transformation (Ramaswamy, Li, \& Petitt, 2012), our research suggests that in emerging economies additional agency cost due to business group structure makes entrenchment arguments more dominant. This is specifically applicable in case of entrepreneurial implication as business group affiliation suppresses EO in group affiliated firms compared to un-affiliated firms. The results of our inquiry stand in contrast to the entrepreneurial benefits of business group affiliation due to its' organizational form as found by previous research on Indian business groups (Manikandan \& Ramachandran, 2015) and the positive innovation performance by Chinese business group affiliated firms (Choi, Lee, \& Williams, 2011). Second, we offer internationalization as one way that a group affiliated firm is able to redirect its focus towards EO. Our finding integrates two different theoretical strands-external network from international market (Johanson \& Vahlne, 2009) and internal network due to links within the business group (Lamin, 2013; Mahmood, Zhu, \& Zaheer, 2017)-to provide greater understanding of the pathways for achieving entrepreneurial outcomes. Third, building on the complementary link between organizational characteristics of a business group and a firm's economic performance, we find that the availability of resources (capital, management and labor, coordinated political

\footnotetext{
1 https://www1.nseindia.com/products/content/equities/indices/nifty_500.htm
} 
lobby) within the business group should be factored in the overall resource profile of the affiliated firm, as eventually the overall resource condition matters to the firm level entrepreneurial outcomes (Covin \& Miles, 2006). This finding enhances our understanding of the entrepreneurial implications of strategic resources within the network of business groups (Chang \& Hong, 2000; Joe \& Oh, 2017).

\section{Theoretical background}

Historically, research on business groups in the emerging economy context concentrated mainly on understanding the economic implications of group affiliation (Carney et al., 2018; Khanna \& Palepu, 2000). We know from prior research that business group affiliation has several implications for affiliated firms such as facilitating global expansion (Kumar, Gaur, \& Pattnaik, 2012) and diversification into new industries (Zhu \& Chung, 2014), and for other firms as well such as adoption of business group structure by foreign firms (Bucheli, Salvaj, \& Kim, 2019). There is a growing stream of research on the innovation in business group affiliated firms e.g. the substitutive and complementary role of institutions on the effect of business group affiliation on innovation (Wang, Yi, Kafouros, \& Yan, 2015), effect of interfirm network governance on innovation management (Li \& Yayavaram, 2021), and facilitating role of business group affiliation in producing more innovations (Choi et al., 2011). The key theoretical arguments in these studies are mostly anchored in the institutional voids view. For example, it is widely understood that business group is a structural response in emerging economies to become innovative or that business group affiliated firms are better positioned to leverage institutional conditions to improve innovation performance (Chang, Chung, \& Mahmood, 2006; Mahmood \& Mitchell, 2004). In these papers, the focus was to understand the role of business group affiliation in providing intermediate governance structures to fill up institutional voids (Chacar \& Vissa, 2005; Manikandan \& Ramachandran, 2015). Relatively little attention, however, has been paid to incorporate the entrenchment view to understand how business group affiliation in emerging economies influences more broader entrepreneurial implication for affiliated firms. The entrenchment view takes the position that firms in business groups generally utilize pyramidal structures and opaque governance (Bertrand et al., 2002) to organize and manage transactions within the group (Jia et al., 2013). From this perspective, the main purpose of a business group structure is to transfer profits among its units to benefit the controlling owners through 'tunneling' (Bae, Kang, \& Kim, 2002; Masulis et al., 2011). Hence, business group results in expropriation of minority investors, as profits are redirected within the group (Purkayastha et al., 2021b; Young, Peng, Ahlstrom, Bruton, \& Jiang, 2008).

Anecdotal evidence so far supports the equivocal entrepreneurial possibilities for business group affiliated firms. One such firm is AFCO Industrial and Chemicals Limited which is one of the forty-eight affiliates of Wadia (popularly known as Bombay Dyeing) business group from India. This organization neither has any presence in any foreign market nor has invested any capital into innovation. AFCO Industrial and Chemicals Limited has not demonstrated any entrepreneurial orientation and, as 
expected, has demonstrated poor financial results in the recent past (-2\% return on assets during 2009-2014). In contrast, Tata Motors (an automobile affiliate in the Tata Group in India) has continuously demonstrated entrepreneurial orientation, including acquisition of the brands Land Rover and Jaguar while manufacturing the 'Nano', the world's cheapest car. Tata Motors has demonstrated an impressive performance (153.44\% stock price appreciation) on the Bombay Stock Exchange (largest stock exchange in India) since 2005. Given conflicting anecdotal evidence, the effect of business group affiliation on EO, which includes risk-taking and proactive behaviors of affiliated firm in addition to innovation, seems a useful area for systematic scientific inquiry.

Our focus on EO is based on the growing understanding among researchers that the conditions in the global economic environment demand emerging economy firms to become more entrepreneurial for survival and success (Bruton, Filatotchev, Si, \& Wright, 2013; Thakur-Wernz, Cantwell, \& Samant, 2019). Kuratko (2007: 189) echoes the prevalent view in the organizational literature when he notes that "entrepreneurial actions are recognized widely as the path to competitive advantage and success in organizations of all types and sizes". According to Ireland, Covin, and Kuratko (2009), EO is increasingly recognized as a strategic behavior that firms choose to pursue when environmental upheavals trigger the need for change and adaptation. By pursuing an entrepreneurially oriented behavior, firms are able to place themselves in a position to regularly and systematically build competitive advantage, which is central to their continuing success (Covin \& Miles, 2006). A prominent stream of research conceives EO as the simultaneous exhibition of three entrepreneurial tendencies- innovativeness, proactiveness, and risk-taking- in a firm's strategic posture (Covin \& Slevin, 1989). Innovativeness refers to a firm's active search efforts to discover and introduce new offerings and ways of doing things. Risk-taking involves exploration of new products or services that deviate from paths previously tried. Proactiveness refers to a firm's ability to act in anticipation of new trends and unforeseen changes (Covin \& Slevin, 1991; Covin \& Wales, 2012). Firms that simultaneously engage in innovative, risk-taking and proactive behaviors with some consistency are typically viewed as dynamic and flexible entities as they are well prepared to capitalize on new opportunities to introduce future goods and services to the market (Covin \& Slevin, 1991).

The institutional environment has direct influence on the firm's behavior as institutional characteristics circumscribe the set of choices available to individuals and organizations (Hill, 1995; Wan \& Hoskisson, 2003). To uncover contingent effect of change in institutional context under which business groups operate, we further focus on the change in both internationalization of the firm and its performance as potential moderators.

\section{Hypotheses development}

\section{Effect of business groups affiliation on entrepreneurial orientation}

The unique organizational and governance characteristics of business groups are the guiding principles that regulate the focus of decision makers of the business groups' 
affiliated firms in realizing the controlling shareholder's goals. There are three key reasons why the entrenchment view may override the institutional voids arguments in case of EO in business group affiliated firms compared to un-affiliated firms.

First, the distinctiveness of a business group structure stems from reliance of affiliated firms on a complex web of mechanisms, such as familial affiliation between top managers, multiple and reciprocated equity, debt, and commercial ties to maintain internal coordination over a collection of heterogeneous firms (Khanna \& Yafeh, 2007). Though there are certain benefits of such organizational structure, including providing the missing markets or filling up institutional voids (Castellacci, 2015) and positively (with diminishing effect) influencing a firm's economic performance through monitoring and advisory services (Sauerwald, Heugens, Turturea, \& Van Essen, 2019), it comes with an additional agency cost as well (Young et al., 2008). Through their controlling stakes, owners and decision-makers in business groups exercise questionable corporate governance practice such as 'tunneling' to expropriate and transfer profits from firms where they have low cash flow rights (Bertrand et al., 2002; Morck \& Yeung, 2003). ${ }^{2}$ Increasing level of related party transactions as a form of tunneling behavior is empirically supported between parent firm and other firms in Chinese business groups (Jia et al., 2013). Consequently, the investment principal in business groups is based on the possibility of greater appropriation of cash at the expense of minority shareholders. On the other hand, investment into EO indicates proactive investment into risk-taking ventures that potentially will create innovative outcomes. Hence, we expect a weaker capital commitment into EO by business group affiliated firms compared to un-affiliated firms.

Second, proactiveness from a firm as propensity to spontaneously and aggressively compete with industry rivals (Covin \& Slevin, 1991) demands business group affiliated firms to take independent investment decisions. Though business group affiliated firms have access to group level surplus resources (Elango \& Pattnaik, 2007) and affiliated firm with prominent position (or firm's centrality in group network) within the business group is more responsive in foreign firm's investment in the home market (Ayyagari, Dau, \& Spencer, 2015), the position in general of an affiliated firm in a business group structure compels the affiliated firm's manager/s to attend primarily to those opportunities that align with the strategic goals of the overall business group (Ren \& Guo, 2011). This is because an affiliated firm is constrained by the business group's direction as well as its' social and organizational relationships with the other actors within the group. This condition might not allow the business group affiliated firm to adopt independent strategic decisions without going through the process of obtaining approval from stakeholders at the group headquarters (Khanna \& Rivkin, 2001). While articulating sources of relative independence of business group affiliated firms (even when they are part of heterogenous business group) compared to $\mathrm{M}$-form organizational structure, Manikandan and Ramachandran (2015: 602) acknowledged that affiliated firms in business groups

\footnotetext{
2 Though Purkayastha, Veliyath, and George (2019) found that controlling ownership structure positively impacts the shareholder value of family owned and non-family managed emerging market firms, we are specifically focusing here only on business group setup.
} 
are "not immune from the influences of the common dominant owner or the group headquarters". Similarly, Bhaumik, Estrin, and Mickiewicz, (2017: 602) found that a firm's adoption of proactive strategies "increase at lower rate for business groups affiliates than for independent companies". We argue that the weaker power position of individual affiliated firms within a business group, in comparison with the group headquarters, discourages affiliated firms from proactively taking high-risk decisions or acting in an entrepreneurially orientated manner.

Third, business group headquarters create informal ties between its affiliated firms, which is especially relevant in the context of emerging markets where formal institutional norms are still developing (Manikandan \& Ramachandran, 2015). This organizational setup gives the management in the group headquarters a stronger say in high-risk projects of the affiliated firms. Also, this centralized structure may not allow them to focus on all projects of each affiliated firm which otherwise would have been beneficial for the affiliated firm. A business group affiliated firm is also obliged to get inputs from other affiliated firms of the business group (even when it is not an efficient process as the various firms may be operating in different industries) due to group and family ownership considerations prevalent in emerging economy firms (Chacar \& Vissa, 2005; Chang \& Hong, 2000). This social norm of involving multiple stakeholders is both an organizational as well as a governance characteristic of a business group structure. It makes affiliated firms conform with the group norms rather than proactively embracing risk-taking ventures or demonstrating EO behavior. Our argument of an affiliated firm's aversion to risktaking due to group affiliation is in contrast with Bhaumik et al.'s (2017: 248) assertion that "business group affiliation increases the firm's ability to assume risks by weakening the detrimental impact of risk-taking on enterprise performance". The difference here is that we are focusing on the lack of inclination towards risk-taking as a strategic behavior of a business group affiliated firm whereas Bhaumik et al. (2017) focused on risk-taking ability.

Based on the logic outlined above, we argue that the structural characteristics (manifested due to heterogeneity within a business group) of a firm's business group affiliation translates into tunneling of financial slacks into other business group affiliated firms, overriding the power of group headquarters in the strategic decision making of an affiliated firm, and an alignment to strategic conformity. As each of these has a detrimental effect on EO, we posit:

Hypothesis 1 (H1): Compared to un-affiliated firms, a firm's business group affiliation is negatively associated with the level of entrepreneurial orientation in an affiliated firm.

\section{Moderating role of internationalization}

A firm's internationalization exposes it to a different type of institutional environment (Peng et al., 2008) compared to the environment available for operating only in the domestic market. In addition, emerging economy firms particularly encounter a greater level of liability of foreignness due to a lack of firm specific assets such as technology, brand etc. when they expand into the international market 
(Gaur, Kumar, \& Sarathy, 2011). These firms also need to overcome the liability of emergingness as the organizational processes in an emerging economy are relatively less developed compared to the governance standards followed in most developed markets (Madhok \& Keyhani, 2012) and their path towards emergingness may be different based on their unique experience of the host environment. To overcome the liability of foreignness and emergingness, emerging economy firms adopt an isomorphic behavior and comply with higher levels of governance standards when they expand into developed international market (Aguilera \& Crespi-Cladera, 2016). Therefore, greater level of internationalization will make the prevailing governance practices such as 'tunneling' (which is detrimental for an affiliated firm to become entrepreneurial) less pronounced in the business group affiliated firm. Further, exposure to a greater competitive environment (which is applicable irrespective of whether the host environment is developed or emerging), due to an increasing level of international expansion, also makes the business group owners more careful in adopting questionable business practices (Karuna, 2007). Hence, international expansion of business group affiliated firms will reduce the negative effects of business group affiliation on EO for those affiliated firms more than that in case of an un-affiliated firm.

Emerging economy firms need to upgrade quality and technology to meet requirement from foreign stakeholders and make proactive investment into highrisk projects when they expand into international market (Piperopoulos et al., 2018; Purkayastha et al., 2021b). Internationalized business group affiliated firms are forced to relax some restrictions and control imposed by the group headquarters in order to meet the expectations from foreign stakeholders. Affiliated firms also face less pressure to give back profits from internationalization to the business group owners due to the presence of slack resources at the group level. Under similar conditions, un-affiliated firms face competitive demands to share the profits from international markets in the form of dividends to their shareholders. The constraints laid down by the business group headquarters reduces with an increasing level of international expansion and hence, business group affiliated firms have greater flexibility to proactively invest back earnings from its internationalization into existing businesses. These changes (lesser control and greater financial freedom) owing to internationalization allows affiliated firms to demonstrate a greater extent of entrepreneurially oriented behavior.

A firm's internationalization increases its operational and management complexity due to requirements of cross border coordination within the firm (Bartlett \& Ghoshal, 1988). The key internal stakeholders in a business group, such as the management team in the group headquarters or the controlling owners, have limited bandwidth to micro-manage the increasing challenges from international expansion. Therefore, an affiliated firm's international expansion allows it to reduce its propensity towards strategic conformity with the headquarters or other affiliated firms. Due to the greater level of international exposure, affiliated firms enjoy greater freedom to engage in proactive investment into new ventures and thereby leaning towards a risk-taking behavior. In contrast, un-affiliated firms do not receive any such additional impetus towards EO as they are not constrained by the prevailing operational and social norms faced by business group affiliated firms. Hence, international 
expansion will reduce the negative association between business group affiliation and risk-taking behavior in affiliated firms. Hence, we hypothesize:

Hypothesis 2 (H2): Compared to un-affiliated firms, the negative effect of business group affiliation on the affiliated firm's entrepreneurial orientation will be alleviated for firms with higher degree of internationalization.

\section{Moderating role of firm performance}

The continuing presence of owners in the management of a business group in the emerging economy creates principal-principal agency costs (Young et al., 2008) and influences affiliated firm's ability to invest into innovation, as profit is disproportionately appropriated through tunneling of resources from affiliated firms (Bertrand et al., 2002). We argue that this movement of financial resources will be less prominent for the affiliated firm that is struggling to deliver a superior economic performance. Rather, those financially weak firms receive the business group's direction and financial resources to identify and invest into strategic investment opportunities (Kim, Hoskisson, Tihanyi, \& Hong, 2004; Manikandan \& Ramachandran, 2015). Poorly performing affiliated firms also receive readily available strategic capabilities from other affiliated firms to proactively invest into innovation or risky endeavors to develop an entrepreneurial posture which is possible only due to the group affiliation (Covin \& Slevin, 1991). Under similar circumstances of poor economic performance, an un-affiliated firm would be compelled to direct its' efforts more towards survival (rather than investment into innovation or risky projects) due to a lack of access to slack resources. Hence, adverse financial conditions make affiliated firms shift their focus more towards entrepreneurial strategic behavior with the help of supportive group-level resources whereas an un-affiliated firm will show the opposite behavior, that is, decreased EO.

Proactiveness in entrepreneurial behavior involves "forward-looking, first mover advantage-seeking efforts to shape the environment by introducing new products or processes ahead of the competition" (Lyon, Lumpkin, \& Dess, 2000: 1056). Any such strategic effort requires availability of strategic resources in the form of financial resources and management bandwidth. In the absence of a well-developed domestic capital and labor markets in an emerging economy, poorly performing un-affiliated firms struggle to procure such strategic resources in the competitive domestic market. Compared to that, poorly performing business affiliated firms receive group level support as the group headquarters arranges capital required for new projects as well as management talent that is critical to production at a lower transaction cost (Chittoor, Kale, \& Puranam, 2015). Thus, when a business group affiliated firm is in a weak financial condition, the firm's level of performance alleviates the negative effect of group affiliation on EO compared to an un-affiliated firm.

Institutional transformations facilitate emerging economy firms to adopt multiple high risk strategies such as borrowing significantly to fuel growth aspiration and committing a critical amount of resources to the projects with uncertain outcomes (Gubbi, Aulakh, \& Ray, 2015). Adverse financial conditions deter un-affiliated firms in these economies from proactively pursuing risky endeavors, as attention of the 
firm is towards efficient utilization of existing resources to improve its' weak economic performance. Contrary to this, business group affiliation allows poorly performing affiliated firms to deviate from strategic conformity as it has access to a coordinated political lobby for preferential treatment in the transforming domestic institutional environment (Ghemawat \& Khanna, 1998). Thus, financially weak affiliated firms can better leverage pro-market institutional reforms in an emerging economy compared to an un-affiliated firm in order to adopt entrepreneurial behavior. Hence, we hypothesize:

Hypothesis 3 (H3): Compared to un-affiliated firms, the negative effect of business group affiliation on the affiliated firm's entrepreneurial orientation will be alleviated for firms with weak performance.

\section{Methods}

\section{Data and sample}

Data from Indian firms, both affiliated with business groups as well as un-affiliated firms, were used to test our predictions. Indian firms are suitable for our investigation in this research as these firms represent characteristics of emerging economies in general, and more specifically the large economies in Asia. First, business groups continue to have a significant presence in the Indian economy even after economic liberalization in 1991 (Ahluwalia, 2002; Kedia, Mukherjee, \& Lahiri, 2006). Firms belonging to business groups constitute about one-third of total number of firms in India, and are responsible for over two-third of revenues and profits earned by Indian firms as a whole (Chittoor et al., 2015). Second, Indian business groups have shown an increasing inclination towards internationalization since the adoption of market based economy in 1991 (Contractor, Kumar, \& Dhanaraj, 2015) and global expansion is an important strategic decision for Indian affiliated firms (Gaur \& Kumar, 2009; Gubbi et al., 2015). Third, unlike business groups in other countries, Indian business groups do not have active government participation and the actions that business groups take are independent and free from responses dictated by external agencies (Purkayastha, Kumar, \& Lu, 2017). Fourth, identification of business group affiliation in Indian firms is clear and unambiguous, which increases reliability and validity of our research. In addition, information for measuring EO and performance for Indian firms is available consistently over time from secondary sources, which strengthens future replicability of our research.

We obtained firm specific data for a fourteen-year period (2006-2019) from the Prowess database of the Centre for Monitoring Indian Economy (CMIE). Prior research has used this database to derive information about Indian business groups (Chittoor et al., 2015; Purkayastha, 2018). Considering that the Indian economy has gone through a significant transformation since 1991, we considered data since 2006 (15 years after 1991) to avoid any effect of institutional transformation in our analysis. We started with NIFTY 500 which represents the top 500 Indian companies. NIFTY 500 Index represents about $96.1 \%$ of the free float market capitalization of 
the stocks and approximately $96.5 \%$ of the traded value of all stocks listed on NSE (one of the major stock markets in India) as on March 29, 2019. ${ }^{3}$ As Prowess database has missing data for smaller firms, we limit our sample to only NIFTY 500 firms. As a result, we make fewer adjustments and assumptions to populate missing data fields than is the case with other researchers using Prowess data (e.g., Gaur \& Delios, 2015). It also enables further comparison of our findings with the equivalent index in development market e.g. S\&P 500 in USA.

We eliminated 58 government-owned enterprises and 21 foreign-owned subsidiaries in India as they are not relevant to our research focus. We also eliminated firms with more than 100 export intensity, more than $100 \%$ debt-to-equity, and any duplicate entries. Also, in order to mitigate endogeneity problems of the independent and moderating variables, we lag the variables by one time period. Thus, our dependent variable is from 2007-2019 time period whereas corresponding independent and control variables are from 2006-2018 time period respectively. In summary, our final sample is an unbalanced panel of 4651 firm-year observations from 406 firms over a thirteen-year time period. Out of 406 firms, 256 are affiliated to business group whereas 150 firms are un-affiliated firms. Some of the key industries in our sample are drugs \& pharmaceuticals (27 firms), computer software (20 firms), other automobile ancillaries (13 firms), business services and consultancy (12 firms), and cement (11 firms).

\section{Measures}

Entrepreneurial orientation (EO). Following prior research, we operationalized EO as a gestalt construct comprising of innovativeness, proactiveness, and risk-taking (Covin \& Slevin, 1989; Miller, 1983). As our sample comprises of large publicly traded firms, we use Miller and Breton-Miller's (2011) operationalization to individually measure the dimensions- innovativeness, proactiveness, and risk-taking and then measure EO as an aggregate effect of all three dimensions, which has since gained some traction in the literature (e.g., Purkayastha et al., 2021a).

As innovativeness, we are primarily interested in the firms' innovation efforts. There are two sides of the innovativeness - first, effort invested into innovation and second, actual outcome through innovativeness. Thus, we considered R\&D investment that measures investment into innovation (Hitt, Hoskisson, \& Kim, 1997) whereas patents which indicates outcome from the of innovativeness (Joshi \& Nerkar, 2011). We measure innovativeness as sum of standardize value of (i) the ratio of $R \& D$ expense to total sales and (ii) the ratio of net patents and copyrights to total sales. ${ }^{4}$ We believe that our composite measure captures the innovativeness of the firm in a comprehensive manner.

\footnotetext{
3 https://www1.nseindia.com/products/content/equities/indices/nifty_500.htm

4 Prowess calculates net value of patents and copyrights at the end of accounting period. The net value of patents and copyrights is derived by deducting cumulative depreciation from the gross value.
} 
We measure proactiveness as the percentage of annual earnings reinvested within the company or retained earnings as $\%$ of profit after tax. We want to capture proactiveness as a firm's active effort and tendency to adopt strategies that builds resources to take bolder actions in near future. Retained earnings are a critical source of financial investment especially at growth and expansion stages of the firms (Scott \& Bruce, 1987) and an overall indicator of proactiveness of the firms.

We capture risk-taking as fluctuation in firm's market evaluation due to its strategic moves. Broadly speaking, firm risk-taking can be separated into two parts- systematic risks associated with market and industry and unsystematic risks ascribed to firm strategy. We measure firm idiosyncratic or unsystematic risk as volatility in stock price ${ }^{5}$ not associated with industry or economic fluctuations (Bansal \& Clelland, 2004).

Values for the three dimensions were standardized and added to obtain an overall summative index measure of EO (Damantopoulos \& Winklhofer, 2001). ${ }^{6}$

Business group affiliation (BGA). Following prior research, we used dummy variable to operationalize BG affiliation (Manikandan \& Ramachandran, 2015). The variable takes a value of 1 if the firm is affiliated to a business group, else 0 for un-affiliated firms. Our operationalization can be criticized for being time-invariant due to the possibility that firms may change ownership over a period of time (Chittoor et al., 2015). In this regard, Khanna and Palepu (2000) observed that firms show remarkable stability over time with regard to business group affiliation. Thus, we believe our time-invariant operationalization of business group affiliation is an acceptable assumption.

Internationalization (DOI). Following Singla and George (2013), we used a composite measure to capture comprehensive value of degree of internationalization (DOI) as sum of three ratios (i) foreign sales to total sales (FSTS), (ii) foreign assets to total assets (FATA), and (iii) number of overseas subsidiaries to total number of overseas (OSTS). Therefore, DOI has a theoretical range of 0 to 3 . We measured internationalization as firm specific construct as we are interested to explore contingent effect of the firm level internationalization on the effect of business group affiliation on EO in affiliated firm compared to un-affiliated firm.

Performance (Perf). We used accounting-based financial performance- Return on Assets (ROA) measured as profit before interest and tax divided by total assets (Lu $\&$ Beamish, 2001) to capture financial performance of the firm. As our conceptual variable is 'weaker state of financial performance', we subtract ROA value from 1 to measure the variable. To elaborate, if a firm has .35 as ROA, the performance of the

\footnotetext{
5 We use standard deviation of the weighted average price at which the shares of a scrip have been traded on National Stock Exchange in a day.

6 Alternative measurement of the EO using different weights for each of the three dimensions are used as robustness test.
} 
said firm is .65 and if the firm has -.35 as ROA, the performance variable takes the value of -1.35 to indicate state of financial performance.

Control variables. To provide a robust test of our predictions, we controlled for a comprehensive set of variables. We included group size to account for the effect of business group size on EO (Chari, 2013), which was measured as natural logarithm value of the group's total assets. We controlled for firm's investment in marketing capabilities as such firms might have higher EO (Teece, 2014) by measuring marketing and advertisement expenses as a proportion of total sales (marketing intensity). We included firm age (years since incorporation) to account for experience, firm size (natural logarithm of net sales revenues of a firm in each year) to control for effect of tacit knowledge, and leverage (debt-to-equity ratio) to control for effect of capital structure on EO. It is important to distinguish firms with high family shareholder concentration from those with low concentration as business groups affiliated firms may cater more to the family stockholders than public shareholders. To control such scenarios, we use promoter block holding $(\mathrm{PBH})$ as proportion of shares held by promoters. We also controlled the influence of foreign venture capital investors on firm's EO as the proportion of shares held by foreign institutional investors as nonpromoters. Presence of foreign institutional investors also influences firm's ability to develop EO. Therefore, we measured the same as proportion of shares held by foreign venture capital investors as non-promoters. We also controlled the industry effect as it takes 1 when the firm is in service industry, else 0 . To empirically control for heterogeneity at the group-level, we add business group diversity (BGD)- measured as Jacqemin-Berry's Entropy measurement (Palepu, 1985)- $\sum_{\mathrm{i}=1}^{\mathrm{N}} \mathrm{P}_{\mathrm{i}} * \ln \left(1 / \mathrm{P}_{\mathrm{i}}\right)$ where $P_{i}$ is the share of the ith industry segment in the total sales using the five digit industry classification (National Industrial Classification code) (Chari, 2013). Finally, we included time dummies to control effect of study period and industry dummies (measured as two-digit industries grouped in a range of 10 NIC Code range) to control industry effect. Table 1 provides formal definitions for all variables used in this study.

\section{Model specification}

Random effect generalized least-squares (GLS) panel regression procedure was used to test the predicted relationships. GLS models provide corrections for the presence of autocorrelation and heteroskedasticity in pooled time series data. It was not possible to conduct Hausman test to compare suitability between random effects and fixed effects as our independent variable (group affiliation) is time-invariant (Kennedy, 1998). We therefore opted for random-effects procedure. The equation used to test hypothesis $\mathrm{H} 1$ is $\mathrm{EO}_{\mathrm{i}, \mathrm{t}+1}=\alpha+\beta^{T *} \mathrm{X}_{\mathrm{i}, \mathrm{t}}+\lambda_{1} * \mathrm{BGA}_{\mathrm{i}}+\mathrm{a}_{\mathrm{i}}+\mathrm{u}_{\mathrm{i}, \mathrm{t}}$ (1), hypothesis $\mathrm{H} 2$ is $\mathrm{EO}_{\mathrm{i}, \mathrm{t}+1}=\alpha+\beta^{T *} \mathrm{X}_{\mathrm{i}, \mathrm{t}}+\lambda_{1} * \mathrm{BGA}_{\mathrm{i}}+\lambda_{2} * \mathrm{DOI}_{\mathrm{i}, \mathrm{t}}+\lambda_{3} * \operatorname{Perf}_{\mathrm{i}, \mathrm{t}}+\lambda_{4} * \mathrm{BGA}_{\mathrm{i}} * \mathrm{DOI}_{\mathrm{i}, \mathrm{t}}+\mathrm{a}_{\mathrm{i}}+\mathrm{u}_{\mathrm{i}, \mathrm{t}}$ (2), and hypothesis $\mathrm{H} 3$ is $\mathrm{EO}_{\mathrm{i}, \mathrm{t}+1}=\alpha+\beta^{T *} \mathrm{X}_{\mathrm{i}, \mathrm{t}}+\lambda_{1} * \mathrm{BGA}_{\mathrm{i}}+\lambda_{2} * \mathrm{DOI}_{\mathrm{i}, \mathrm{t}}$ $+\lambda_{3} * \operatorname{Perf}_{\mathrm{i}, \mathrm{t}}+\lambda_{4} * \mathrm{BGA}_{\mathrm{i}} * \operatorname{Perf}_{\mathrm{i}, \mathrm{t}}+\mathrm{a}_{\mathrm{i}}+\mathrm{u}_{\mathrm{i}, \mathrm{t}}$ (3) where subscripts refer to firm $\mathrm{i}$ at time $t, \alpha$ is intercept, $\beta^{T}$ is regression coefficient matrix for control variables, $X_{i, t}$ is control 
Table 1 Variable Definitions

\begin{tabular}{|c|c|}
\hline Variable name & Definition \\
\hline \multicolumn{2}{|l|}{ Dependent variable } \\
\hline Entrepreneurial Orientation (EO) & $\begin{array}{l}\text { Sum of standardized values for innovativeness, proactiveness, } \\
\text { and risk-taking (as defined below) }\end{array}$ \\
\hline Innovativeness & $\begin{array}{l}\text { Sum of (i) ratio of R\&D expense to total sales and (ii) ratio of } \\
\text { net Patents \& copyrights to total sales }\end{array}$ \\
\hline Proactiveness & $\begin{array}{l}\text { Percentage of annual earnings reinvested within the company: } \\
\text { retained earnings as \% of profit after tax }\end{array}$ \\
\hline Risk-taking & $\begin{array}{l}\text { Unsystematic risk: volatility in stock price not associated with } \\
\text { industry or economic fluctuations measured as standard devia- } \\
\text { tion of monthly stock price on yearly basis }\end{array}$ \\
\hline \multicolumn{2}{|l|}{ Independent variable } \\
\hline Business Group Affiliation (BGA) & $\begin{array}{l}\text { Takes a value of } 1 \text { if the firm is affiliated to a business group, } \\
\text { else } 0 \text { for un-affiliated firms }\end{array}$ \\
\hline \multicolumn{2}{|l|}{ Moderating variable } \\
\hline Degree of Internationalization (DOI) & $\begin{array}{l}\text { Sum of (i) ratio of foreign sales to total sales, (ii) ratio of } \\
\text { foreign assets to total assets, and (iii) ratio of number of } \\
\text { overseas subsidiaries to total number of overseas }\end{array}$ \\
\hline Performance (Perf) & $1-($ Profit before interest and tax divided by total assets) \\
\hline \multicolumn{2}{|l|}{ Control variables } \\
\hline Group size & Natural logarithm value of the group's total assets \\
\hline Marketing intensity & $\begin{array}{l}\text { Marketing and advertisement expenses as a proportion of total } \\
\text { sales }\end{array}$ \\
\hline Firm size & Natural logarithm of net sales revenues of a firm in each year \\
\hline Firm age & Years since incorporation \\
\hline Leverage & Debt-to-equity ratio \\
\hline Promoter block holding (PBH) & Proportion of shares held by promoters \\
\hline Foreign Venture Capital Investors & $\begin{array}{l}\text { Proportion of shares held by foreign institutional investors as } \\
\text { non-promoters }\end{array}$ \\
\hline Foreign Institutional Investors & $\begin{array}{l}\text { Proportion of shares held by foreign venture capital investors as } \\
\text { non-promoters }\end{array}$ \\
\hline Service Industry & Takes 1 when the firm is in service industry, else 0 \\
\hline Business group diversity (BGD) & $\begin{array}{l}\text { where } \mathrm{P}_{\mathrm{i}} \text { be the share of the ith industry segment in the total } \\
\text { sales using the five digit industries classification (National } \\
\text { Industrial Classification code) }\end{array}$ \\
\hline Time dummies & $\begin{array}{l}\text { Takes value of } 1 \text { if the firm-year is from a specific year, else } 0 \\
\text { for other years }\end{array}$ \\
\hline Industry dummies & Two-digit industries grouped in a range of 10 NIC Code range \\
\hline \multicolumn{2}{|l|}{ Instrumental variable } \\
\hline International Raw Materials (IRM) & Ratio of import of raw materials to sales \\
\hline Cash Flow (CF) & Standardized value of net cash flow from operating activities \\
\hline
\end{tabular}


variables, $\lambda s$ are regression coefficients, $a_{i}$ is firm specific unobserved effect, and $u_{i, t}$ is error term. Our hypotheses have the following implications for the coefficient estimates: (i) $\mathrm{H} 1$ implies $\lambda_{1}<0$ (in Eq. 1), (ii) $\mathrm{H} 2$ implies $\lambda_{4}>0$ (in Eq. 2), and (iii) $\mathrm{H} 3$ implies $\lambda_{4}>0$ (in Eq. 3).

\section{Results}

\section{Descriptive statistics}

Table 2 provides descriptive statistics and correlations. Variance Inflation Factor (VIF) values range from 1.00 to a maximum of 6.59 with mean of 1.70 , suggesting that multicollinearity is not an issue (Hair, Tatham, Anderson, \& Black, 2006). We also note that highly leveraged firms are low in EO $(r=-.04$, significant at less than $.1 \%$ level). About 64 percent of the sample firm-years are affiliated with business groups, while the rest are stand-alone firms. We find $30 \%$ of sample firms are from service industry. We observe that $15.3 \%$ of the overall sales (calculated as dividing $46 \%$ by 3 as we aggregate three ratios to measure degree of internationalization) come from international market in our sample.

\section{Hypothesis testing}

Tables 3 and 4 presents regressions results. In the first step, we entered only control variables (Model 1). In all the models, control variables firm size and promoter block holding are positively associated with the EO. Though we did not hypothesize on this issue, a possible explanation could be the need for slack resources and concentrated ownership to pursue entrepreneurial behaviors (Atuahene-Gima \& Ko, 2001).

The variable for business group affiliation is added in the next step. Wald test chi-square statistics confirms that the inclusion of the business group affiliation term improves model fit (model $2: \chi^{2}=5.3, \mathrm{df}=1, \mathrm{p}=.021$ ). As hypothesized in $\mathrm{H} 1$, business group affiliation has a statistically significant negative association with EO (model 2: $\beta=-.338, p=.021$ ), which supports H1. We add two moderators in model 3. As expected, we receive negative and statistically significant effect (model $3: \beta=-.333, p=.022$ ) of business group affiliation on EO.

Next, we add the interaction term of group affiliation and degree of internationalization to test moderating effect of degree of internationalization in relationship between business group affiliation and EO in model 4 . Wald test chi-square statistics confirms that the inclusion of the interaction term improves model fit (model 4: $\chi^{2}=3.7, \mathrm{df}=1, \mathrm{p}=.055$ ). The coefficient of business group affiliation (model 4: $\beta=-.432, p=.005$ ) is in the expected direction and significant. As hypothesized in $\mathrm{H} 2$, we received statistically significant positive coefficient (model 4: $\beta=.210$, $\mathrm{p}=.055$ ) of interaction term. This confirms that business group affiliated firms have higher EO when there is greater internationalization compared to firms with lower internationalization. 


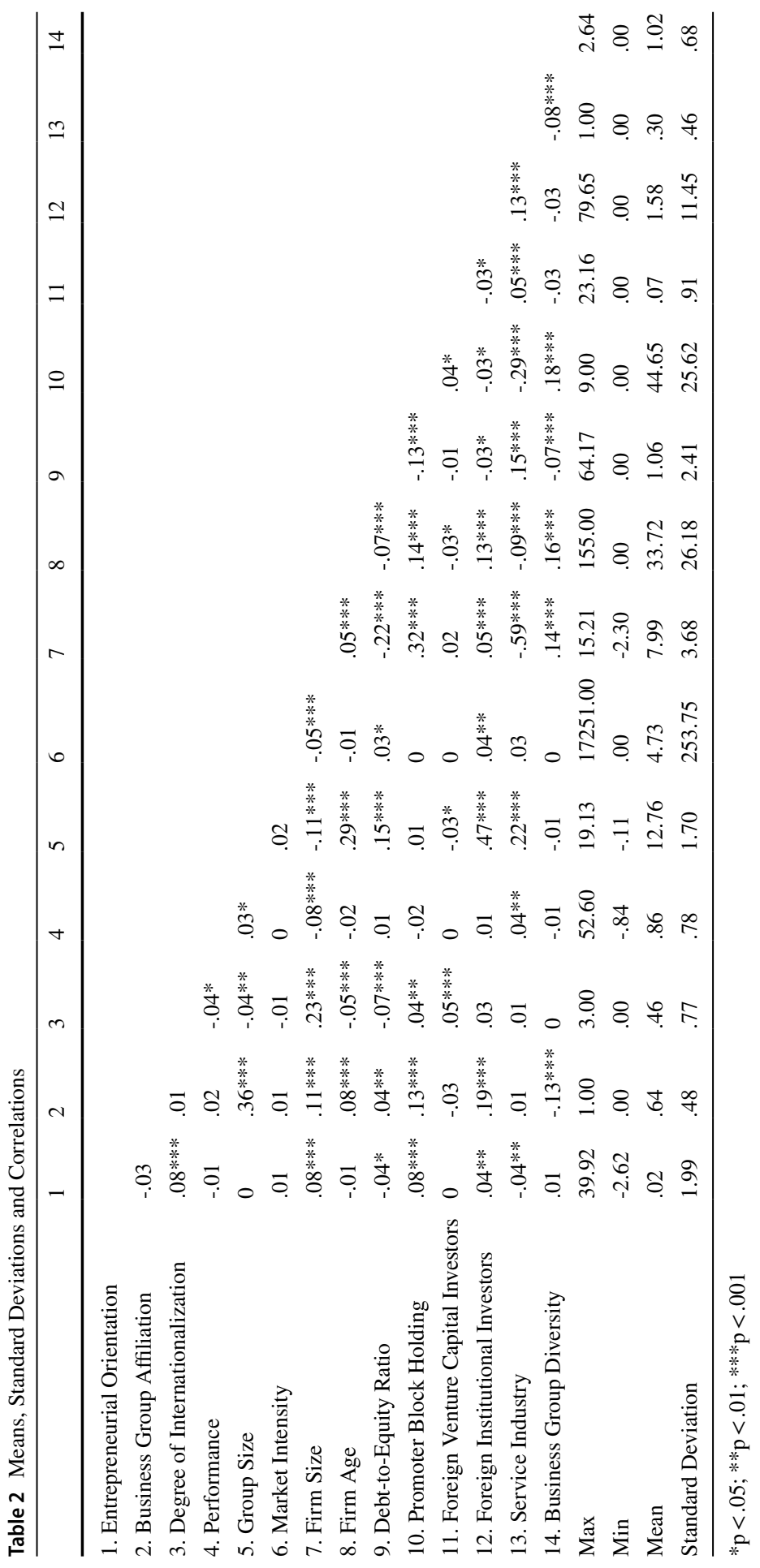


Table 3 Results of Random Effect (RE) Panel Data Regression Analyses

\begin{tabular}{|c|c|c|c|c|c|c|c|c|c|}
\hline \multirow{3}{*}{$\begin{array}{l}\text { RE Models } \\
\text { Dependent variable }\end{array}$} & \multirow{2}{*}{\multicolumn{3}{|c|}{$\begin{array}{l}\text { Model } 1 \text { (Control) } \\
\text { Entrepreneurial } \\
\text { Orientation }\end{array}$}} & \multirow{2}{*}{\multicolumn{3}{|c|}{$\begin{array}{l}\text { Model } 2(\mathrm{H} 1) \\
\text { Entrepreneurial } \\
\text { Orientation }\end{array}$}} & \multirow{2}{*}{\multicolumn{3}{|c|}{$\begin{array}{l}\text { Model } 3 \\
\text { Entrepreneurial } \\
\text { Orientation }\end{array}$}} \\
\hline & & & & & & & & & \\
\hline & Beta & S. E & p-value & Beta & S. E & p-value & Beta & S. E & p-value \\
\hline Intercept & -1.467 & 1.397 & .294 & -1.488 & 1.393 & .285 & -1.471 & 1.386 & .288 \\
\hline Group Size & .041 & .045 & .359 & .075 & .047 & .110 & .079 & .047 & .090 \\
\hline Marketing Intensity & .000 & .000 & .703 & .000 & .000 & .692 & .000 & .000 & .702 \\
\hline Firm Size & .071 & .017 & .000 & .075 & .017 & .000 & .058 & .017 & .000 \\
\hline Firm Age & -.002 & .003 & .452 & -.002 & .003 & .417 & -.002 & .003 & .452 \\
\hline Debt-Equity Ratio & -.014 & .012 & .279 & -.013 & .012 & .282 & -.013 & .012 & .285 \\
\hline $\begin{array}{l}\text { Promoter Block } \\
\text { Holding }\end{array}$ & .004 & .002 & .016 & .004 & .002 & .011 & .004 & .002 & .010 \\
\hline $\begin{array}{l}\text { Foreign Venture } \\
\text { Capital Investors }\end{array}$ & -.008 & .030 & .786 & -.009 & .030 & .758 & -.011 & .030 & .726 \\
\hline $\begin{array}{l}\text { Foreign Institutional } \\
\text { Investors }\end{array}$ & .001 & .004 & .847 & .001 & .004 & .835 & .001 & .004 & .862 \\
\hline Service Industry & .282 & .353 & .424 & .237 & .353 & .501 & .188 & .352 & .593 \\
\hline $\begin{array}{l}\text { Business Group } \\
\text { Diversity }\end{array}$ & .000 & .008 & .994 & -.004 & .008 & .644 & -.003 & .008 & .676 \\
\hline BGA & & & & -.338 & .146 & .021 & -.333 & .146 & .022 \\
\hline DOI & & & & & & & .109 & .057 & .055 \\
\hline Perf & & & & & & & .004 & .033 & .893 \\
\hline BGA $*$ DOI & & & & & & & & & \\
\hline BGA $*$ Perf & & & & & & & & & \\
\hline Year dummies & Included & & & Included & & & Included & & \\
\hline Industry dummies & Included & & & Included & & & Included & & \\
\hline RE Model Indices & & & & & & & & & \\
\hline Wald $\chi^{2}$ & 152.3 & & {$[.000]$} & 157.9 & & {$[.000]$} & 161.9 & & {$[.000]$} \\
\hline Wald test $\chi^{2}(1 / 2)$ & & & & 5.3 & & {$[.021]$} & 43.7 & & {$[.16]$} \\
\hline Adjusted R-square & .026 & & & .027 & & & .027 & & \\
\hline \# of observations & 4651 & & & 4651 & & & 4651 & & \\
\hline Number of firms & 406 & & & 406 & & & 406 & & \\
\hline
\end{tabular}

Next, we add the interaction term of group affiliation and performance to test moderating effect of state of weak financial performance in relationship between business group affiliation and EO in model 5. Wald test chi-square statistics confirms that the inclusion of the interaction term improves model fit (model 5: $\left.\chi^{2}=4.1, \mathrm{df}=1, \mathrm{p}=.043\right)$. As expected, the coefficient on business group affiliation (model 5: $\beta=-.939, \mathrm{p}=.005$ ) is negative and significant. As hypothesized in $\mathrm{H} 3$, we received statistically significant positive coefficient (model 5: $\beta=.734$, $\mathrm{p}=.043$ ) of interaction term. This confirms that weak financial performance makes business group affiliated firm more entrepreneurially oriented compared to un-affiliated firm. 
Table 4 Results of Random Effect (RE) Panel Data Regression Analyses

\begin{tabular}{|c|c|c|c|c|c|c|c|c|c|}
\hline \multirow{3}{*}{$\begin{array}{l}\text { RE Models } \\
\text { Dependent variable }\end{array}$} & \multirow{2}{*}{\multicolumn{3}{|c|}{$\begin{array}{l}\text { Model } 4(\mathrm{H} 2) \\
\text { Entrepreneurial } \\
\text { Orientation }\end{array}$}} & \multirow{2}{*}{\multicolumn{3}{|c|}{$\begin{array}{l}\text { Model } 5(\mathrm{H} 3) \\
\text { Entrepreneurial } \\
\text { Orientation }\end{array}$}} & \multirow{2}{*}{\multicolumn{3}{|c|}{$\begin{array}{l}\text { Model } 6 \text { (Full Model) } \\
\text { Entrepreneurial } \\
\text { Orientation }\end{array}$}} \\
\hline & & & & & & & & & \\
\hline & Beta & S. E & $\mathrm{p}$-value & Beta & S. E & p-value & Beta & S. E & p-value \\
\hline Intercept & -1.374 & 1.381 & .320 & -.691 & 1.440 & .631 & -.523 & 1.436 & .716 \\
\hline Group Size & .082 & .046 & .079 & .055 & .047 & .168 & .057 & .047 & .155 \\
\hline Marketing Intensity & .000 & .000 & .704 & .000 & .000 & .707 & .000 & .000 & .710 \\
\hline Firm Size & .057 & .017 & .000 & .054 & .017 & .000 & .052 & .017 & .000 \\
\hline Firm Age & -.002 & .003 & .416 & -.002 & .003 & .501 & -.002 & .003 & .463 \\
\hline Debt-Equity Ratio & -.013 & .012 & .298 & -.013 & .012 & .281 & -.013 & .012 & .295 \\
\hline $\begin{array}{l}\text { Promoter Block } \\
\text { Holding }\end{array}$ & .004 & .002 & .010 & .004 & .002 & .013 & .004 & .002 & .013 \\
\hline $\begin{array}{l}\text { Foreign Venture } \\
\text { Capital Investors }\end{array}$ & -.009 & .030 & .752 & -.010 & .030 & .742 & -.009 & .030 & .773 \\
\hline $\begin{array}{l}\text { Foreign Institutional } \\
\text { Investors }\end{array}$ & .001 & .004 & .857 & .001 & .004 & .799 & .001 & .004 & .789 \\
\hline Service Industry & .165 & .351 & .638 & .190 & .352 & .589 & .165 & .351 & 638 \\
\hline $\begin{array}{l}\text { Business Group } \\
\text { Diversity }\end{array}$ & -.003 & .008 & .657 & -.004 & .008 & .656 & -.004 & .008 & .634 \\
\hline BGA & -.432 & .154 & .005 & -.939 & .332 & .005 & -1.096 & .340 & .001 \\
\hline DOI & -.017 & .087 & .848 & .104 & .057 & .058 & -.034 & .087 & .700 \\
\hline Perf & .005 & .033 & .886 & -.723 & .361 & .045 & -.782 & .361 & .031 \\
\hline BGA $*$ DOI & .210 & .109 & .055 & & & & .229 & .110 & .037 \\
\hline BGA $*$ Perf & & & & .734 & .362 & .043 & .793 & .363 & .029 \\
\hline Year dummies & \multicolumn{3}{|l|}{ Included } & \multicolumn{3}{|l|}{ Included } & \multicolumn{3}{|l|}{ Included } \\
\hline Industry dummies & \multicolumn{3}{|l|}{ Included } & \multicolumn{3}{|l|}{ Included } & \multicolumn{3}{|l|}{ Included } \\
\hline \multicolumn{10}{|l|}{ RE Model Indices } \\
\hline Wald $\chi^{2}$ & 165.8 & & {$[.000]$} & 166.0 & & {$[.000]$} & 170.7 & & {$[.000]$} \\
\hline Wald test $\chi^{2}(1 / 2)$ & 3.7 & & {$[.055]$} & 4.1 & & {$[.043]$} & 8.5 & & {$[.015]$} \\
\hline Adjusted R-square & .028 & & & .028 & & & .028 & & \\
\hline \# of observations & 4651 & & & 4651 & & & 4651 & & \\
\hline Number of firms & 406 & & & 406 & & & 406 & & \\
\hline
\end{tabular}

In full model with both the moderators, we received expected negative effect of business group affiliation on EO (model 6: $\beta=-1.096, p=.001$ ), positive moderation of internationalization (model $6: \beta=.229, \mathrm{p}=.037$ ) and performance (model $6: \beta=.739, \mathrm{p}=.029)$.

We graphically display the interaction result in Figs. 1 and 2. Figure 1 shows that at higher level of degree of internationalization business group affiliated firms more entrepreneurially oriented compared to un-affiliated firms. Similarly, Fig. 2 indicates that negative effect on EO for business group affiliated firms compared to un-affiliated firms are less pronounced in case weak financial performance. Thus, we demonstrate that presence of higher degree of internationalization and weak 


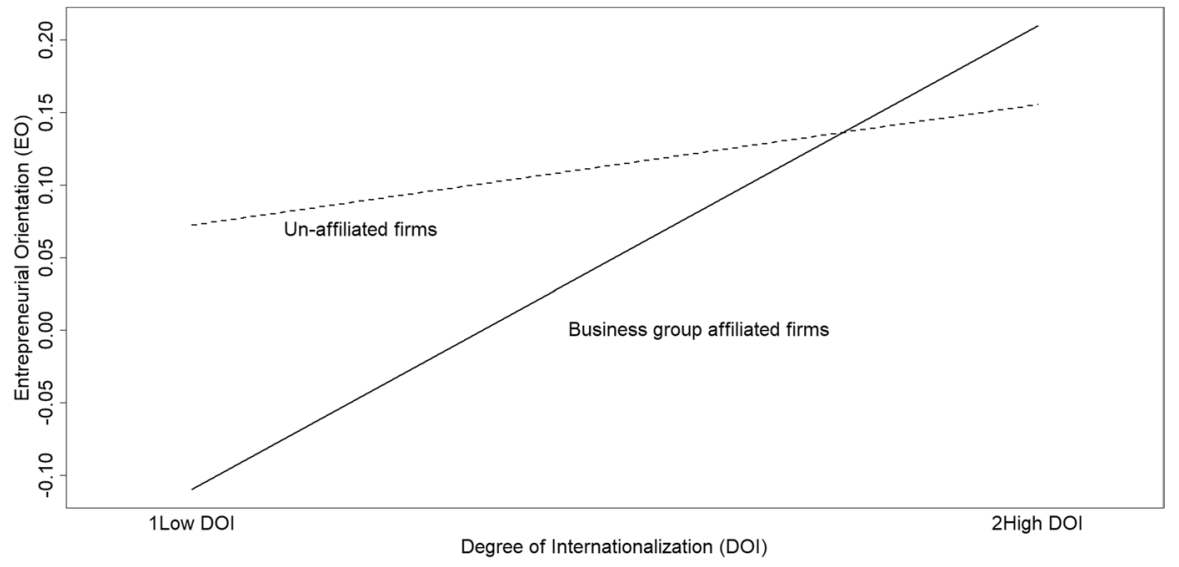

Fig. 1 Moderating Role of Degree of Internationalization on Business Group Affiliation-Entrepreneurial Orientation Relationship

financial performance positively moderates the negative relationship between business group affiliation and EO.

\section{Endogeneity tests}

In $\mathrm{H} 1$, we hypothesized that business group affiliation will lead to lower level of EO. Affiliation with a business group is not generally an after-thought (Khanna \& Palepu, 2000). Consequently, it is unlikely that the level of entrepreneurship in the firm can induce it to become part of a business group, theoretically ruling out the possibility of reverse causality - that is, EO cannot lead to business group affiliation in our model. As further robustness test, we used Gaussian distribution

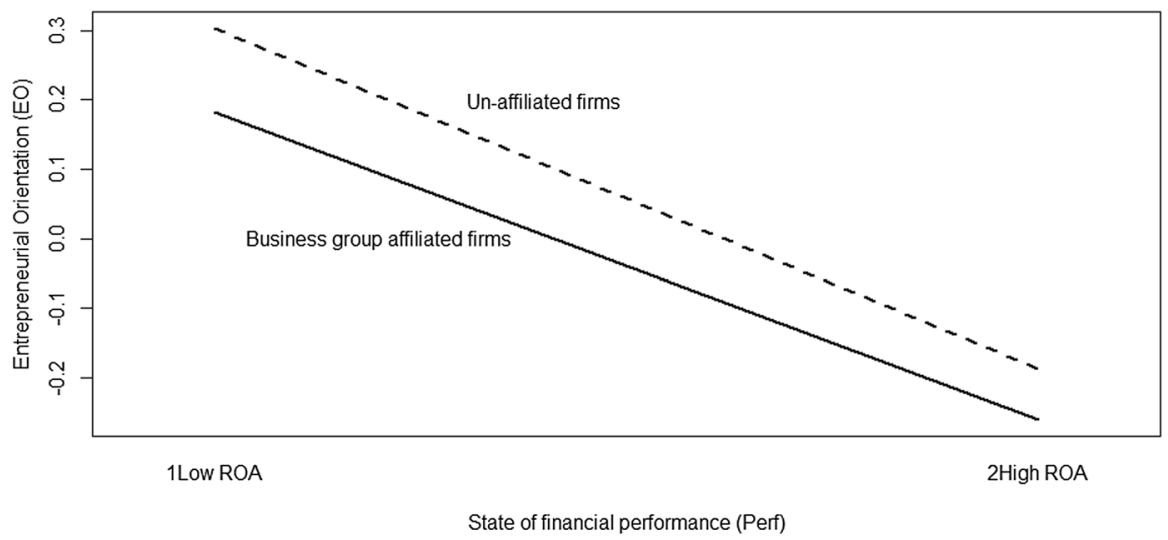

Fig. 2 Moderating Role of Financial Performance on Business Group Affiliation-Entrepreneurial Orientation Relationship 
with random-effect panel data analysis to empirically examine presence of reverse causality, finding an economically negligible and statistically insignificant effect.

In $\mathrm{H} 2$ and $\mathrm{H} 3$, we hypothesized that degree of internationalization and firm's performance moderate relationship between business group affiliation and EO respectively. It is possible that unobserved features of the firm may be correlated with the moderators namely degree of internationalization and firm's performance. Thus, there may be concerns about endogeneity problems stemming from omitted variable bias (Wooldridge, 2012). Following Baltagi (2005), we used instrumental variable and 2SLS method to address possible endogeneity problem.

To estimate instrumental variable regression for panel data, we need an exogenous instrument for the moderators. Good instrument should be correlated with endogenous variable (degree of internationalization and firm's performance) and uncorrelated with error term (Wooldridge, 2012). We identify international raw materials (IRM)- 'extent of import of raw materials' as instrument variable for degree of internationalization and cash flow (CF)- 'net cash flow from operating activities' as instrument variable for firm's performance. Prior literature argued that import of foreign raw materials is an antecedent for expansion into international market emerging economy firms and cash flow determines firm's economic performance. We operationalized IRM as 'import of raw materials / sales' (Chittoor, Sarkar, Ray, \& Aulakh, 2009) and CF as 'standardize value of net cash flow from operating activities'. Hence, theoretically (i) IRM and degree of internationalization and (ii) CF and firm's performance are correlated.

Then, we regressed degree of internationalization on IRM using $\mathrm{DOI}_{\mathrm{i}, \mathrm{t}}=\alpha+\beta^{\mathrm{T} *} \mathrm{X}_{\mathrm{i}, \mathrm{t}}+\lambda_{1} * \mathrm{IRM}_{\mathrm{i}, \mathrm{t}}+\mathrm{a}_{\mathrm{i}}+\mathrm{u}_{\mathrm{i}, \mathrm{t}}$ (4) where subscripts refer to firm $\mathrm{i}$ at time $\mathrm{t}, \alpha$ is intercept, $\beta^{\mathrm{T}}$ is regression coefficient matrix for control variables, $X_{i, t}$ is control variables, $\lambda_{1}$ regression coefficient of IRM, $a_{i}$ is firm specific unobserved effect and $\mathrm{u}_{\mathrm{i}, \mathrm{t}}$ is error term. Likewise, we regressed firm's performance on CF using $\operatorname{Perf}_{\mathrm{i}, \mathrm{t}}=\alpha+\beta^{\mathrm{T} *} \mathrm{X}_{\mathrm{i}, \mathrm{t}}+\lambda_{1}{ }^{*} \mathrm{CF}_{\mathrm{i}, \mathrm{t}}+\mathrm{a}_{\mathrm{i}}+\mathrm{u}_{\mathrm{i}, \mathrm{t}}$ (5) where subscripts refer to firm $\mathrm{i}$ at time $\mathrm{t}, \alpha$ is intercept, $\beta^{\mathrm{T}}$ is regression coefficient matrix for control variables, $X_{i, t}$ is control variables, $\lambda_{1}$ regression coefficient of $C F, a_{i}$ is firm specific unobserved effect and $u_{i, t}$ is error term. We observe statistically significant positive value for IRM $(\beta=.907$, $\mathrm{p}=.00)$ and $\mathrm{CF}(\beta=.002, \mathrm{p}=.09)$. Finally, we estimate Eq. 2 through 2 SLS using IRM as instrumental variable for DOI and Eq. 3 through 2SLS using CF as instrumental variable for Perf.

As third step, we used predicted value of DOI from (4) into (2) to estimate moderating effect of degree of internationalization on business group affiliation and EO relationship and predicted value of Perf from (5) into (3) to estimate moderating effect of firm's performance on business group affiliation and EO relationship. Empirically, these instruments were relevant (IRM: $F=188.706, p=.000$; $\mathrm{CF}: \mathrm{F}=1.75, \mathrm{p}=.030)^{7}$ and significant Durbin-Wu-Hausman test result (IRM: $\mathrm{F}=6.524, \mathrm{p}=.111 ; \mathrm{CF}: \mathrm{F}=.017, \mathrm{p}=.090)$ suggests that the endogeneity corrected model is consistent compared to other models. Finally, we received statistically significant positive coefficient of BGA-DOI interaction term $(\beta=.995, \mathrm{p}=.001)$ and

\footnotetext{
7 Typical rule-of-thumb value of 10 or more to avoid weak instruments (Stock \& Yogo, 2005).
} 
BGA-Perf interaction term $(\beta=1.047, \mathrm{p}=.09)$. These results establish endogeneity corrected positive moderating effect as hypothesized in $\mathrm{H} 2$ and $\mathrm{H} 3$ respectively.

\section{Robustness tests}

As robustness test, we use different composition of EO based on different weights of sub-dimensions (namely, innovativeness, proactiveness, and risk-taking). First, we measure EO with $50 \%$ weightage for innovativeness, $25 \%$ weightage for proactiveness, and $25 \%$ weightage for risk-taking. We received expected negative effect of business group affiliation on EO $(\beta=-.241, \mathrm{p}=.072)$, positive moderation of internationalization $(\beta=.090, \mathrm{p}=.038)$ and performance $(\beta=.185, \mathrm{p}=.019)$. Second, we measure EO with $25 \%$ weightage for innovativeness, $50 \%$ for proactiveness, and $25 \%$ for risk-taking. We received expected negative effect of business group affiliation on EO $(\beta=-.490, \mathrm{p}=.000)$, positive moderation of internationalization $(\beta=.073, \mathrm{p}=.043)$ and performance $(\beta=.327, \mathrm{p}=.006)$. Third, we measure EO with $25 \%$ weightage for innovativeness, $25 \%$ for proactiveness, and $50 \%$ for risk-taking. We received expected negative effect of business group affiliation on EO ( $\beta=-.360$, $\mathrm{p}=.002)$, positive moderation of internationalization $(\beta=.057, \mathrm{p}=.073)$ and performance $(\beta=.287, \mathrm{p}=.019)$.

We also tested hypothesized models with a 2-year lag. Supporting H1, we received expected negative coefficient $(\beta=-1.353, \mathrm{p}=.009)$ for effect of business group affiliation on EO. The positive and significance coefficient for the interaction terms between degree of internationalization and business group affiliation $(\beta=.248$, $\mathrm{p}=.054)$ and performance and business group affiliation $(\beta=1.086, \mathrm{p}=.054)$ provides robustness of our hypotheses $\mathrm{H} 2$ and $\mathrm{H} 3$.

\section{Discussion}

This study deepens our understanding of the costs and benefits of business group affiliation (Carney,Gedajlovic, Heugens, Van Essen, \& Van Oosterhout, 2011; Khanna \& Palepu, 2000) as we specifically investigate whether and when business group affiliation in emerging economy affects EO of affiliated firms. We explain how the unique organizational and governance characteristics of business group affiliation makes the affiliated firms less entrepreneurially oriented compared to unaffiliated firms. We find that the exposure to a greater competitive environment due to different institutional norms in international markets makes business group affiliated firms innovative and proactive while also improving its' capability to handle risky projects. We also find that poor economic performance of an affiliated firm moves its attention towards entrepreneurial behavior whereas an un-affiliated firm restrains its' EO. We received support for our hypothesized model using a longitudinal data set of 419 Indian business group affiliated and un-affiliated firms from NIFTY 500 index over the fourteen-year period from 2006 to 2019.

We find that the focus of the decision makers in business groups is not aligned with EO as, both structurally and strategically, affiliated firms in business groups 
do not embrace innovation, proactiveness and risk-taking. As individual firms make different choices about their strategic orientation, analysis of the EO of business group affiliated firms casts light on a critical governance aspect of having affiliation to business groups (Chakrabarti, Megginson, \& Yadav, 2008; Siegel \& Choudhury, 2012). These findings contribute to the discussion on the contrasting implications of group affiliation as business groups "are likely to have multiple, conflicting, and complementary effects on their host societies and the firms that affiliate with them" (Carney et al., 2011: 454). Theoretically, our finding of a lack of EO in business group affiliated firms adds to idiosyncratic entrenchment issues of business group affiliation in emerging economy such as principal-principal agency problem (Young et al., 2008), cross-subsidization (Bertrand et al., 2002), entry barrier for un-affiliated firm (Pattnaik, Lu, \& Gaur, 2018), and nepotism (Chang \& Hong, 2000). Though group affiliation mitigates the institutional voids arising due to inefficiencies of external markets, our research strengthens the literature that deals with the counterproductive aspects of group affiliation (Feenstra, Hamilton, \& Lim, 2002; Pattnaik et al., 2018). Our research builds on two important and accepted research findings-the significant economic and social role that business groups play in the emerging economy (Chittoor \& Aulakh, 2015; Ramachandran, Manikandan, $\&$ Pant, 2013) and the importance of EO as a source of competitive advantage in such a dynamic environment (Covin \& Miles, 2006). Therefore, our findings educate managers in-charge of business group affiliated firms to make suitable strategic choices to counter negative effect of group affiliation on EO.

The finding about the contingent effect of degree of internationalization to improve the level of EO of affiliated firms enriches our understanding of global strategy in the context of the emerging economy (Elango \& Pattnaik, 2007; Kumar et al., 2020). Earlier literature acknowledges the importance of network as a source of competitive advantages (Ahuja, 2000; Gulati, Nohria, \& Zaheer, 2000) and the same is echoed in Johanson and Vahlne's (2009: 1411) argument that "markets are networks of relationships in which firms are linked to each other in various, complex and, to a considerable extent, invisible patterns". Literature in the context of business group emphasizes value creation of network structure (dense or sparse) or types of network ties (centralization of equity ties) (Mahmood, Zhu, \& Zajac, 2011; Mahmood et al., 2017). We find that business group affiliation does not have a straightforward mono- directional effect on affiliated firm's EO. Network ties within business group makes affiliated firms less entrepreneurially oriented due the effect of tunneling, control from headquarters, and strategic alignment with the group directions. Our research reveals a boundary condition of importance of networks in the business group affiliated firms as the effects of network is contingent on the exposure of the firm to international competition.

Our finding that weak financial performance plays a contingent role in making affiliated firms more entrepreneurial compared to un-affiliated firms indicates the importance of access to resources external to the focal firm. Theoretically, it indicates that organization is dependent on internal resource stocks (Barney, 1991) and its' action is influenced by dependencies on external resources (Pfeffer \& Salancik, 1978). Whereas un-affiliated firms are restrained towards entrepreneurial posture due to lack of supporting financial resources, affiliated firms are able to direct attention 
to EO with the help of the group level and other affiliate's resources. We extend the list of possible actions such as mergers/vertical integration, joint ventures/alliances, inclusion of external board members by the firm to minimize environmental dependences (Hillman, Withers, \& Collins, 2009; Pfeffer \& Salancik, 1978) and submit that business group affiliation is one such structural solution to reduce a firm's external interdependencies and power dependence. Though business group formation is not an after-thought, business group provides an alternative to $\mathrm{M}$-form structure to successfully respond to the external environment of less resource munificence which is prevalent in emerging economies. Hence, we join the recent conversation on valueadding potential of multi-entity organizational form through business group affiliation (Bucheli et al., 2019; Manikandan \& Ramachandran, 2015).

In terms of implications for managers, our research shows that network effect (or EO in this case) of business group affiliation is not static and is dependent on strategy (or global expansion in our study) of the affiliated firm. Improving EO in the affiliated firm with the help of internationalization provides a practically implementable direction to the manager of business group affiliated firm to focus their attention on global expansion. Finally, it also provides an interesting managerial implication that a business group can turn the weak financial performance of an affiliated firm into higher level of EO for that firm. Therefore, unlike un-affiliated firms (where poor economic performance indicates risk of liquidation), business groups should leverage group and other affiliate level resources to invest into the financially non-performing firms and nurture them to improves its EO.

Our study also contributes to emerging economy literature that is specially focusing on entrepreneurial behavior of the business group affiliated firm in these economies (Choi et al., 2011; Mahmood \& Mitchell, 2004; Wang et al., 2015). Prior literature explicitly focused on the entrepreneurial effect of firm-level institutional factors (Wang et al., 2015) and global strategy (Thakur-Wernz et al., 2019). Considering that the business group structure remains a dominant form in most of the emerging economies, we emphasize a possible path for e affiliated firms to improve their EO. Though research on EO in emerging economies is still at its infancy (Gupta \& Batra, 2015), we explain the effect of the firm's behavior (degree of internationalization) and economic state (financial performance) in influencing business group affiliated firm's EO. It is in this context that there is a greater need to shift the academic discussion to examine the entrenchment implications of emerging economy firm's behavior, instead of only efficiency-enhancing role of business group affiliated firms in society (Carney et al., 2018). With a focus on firm specific behavior, this study complements prior studies which highlight the role of institutional transformation in influencing the effect of business group affiliation in emerging economies (Chittoor et al., 2015; Stucchi et al., 2015).

Like any other research, our study also has limitations that open new avenues for future inquiry. First, our focus in this study is to compare entrepreneurial implication of a firm's group affiliation compared to un-affiliated firms. Hence, we use business group affiliation as the dichotomous variable to separate the firms. However, business groups are structurally not same (Chittoor \& Aulakh, 2015) and not all affiliated firms receive similar treatment from the group headquarters ( $\mathrm{Li} \&$ Yayavaram, 2021; Mahmood et al., 2017). A more nuanced research design that 
incorporates some form of business group heterogeneity (Chari, 2013) into its hypothesized conceptual model is therefore warranted to understand entrepreneurial implication within differing business group structures. One specific aspect requires special attention is the effect of centrality of an affiliated firm in influencing EO for itself, other affiliated firms, and business group as a whole. Second, our moderating mechanisms such as international and domestic competitive environments are closely linked with the institutional development (Yiu, Bruton, \& Lu, 2005). In this paper, we did not explicitly incorporate characteristics and development of institutions which are intertwined with entrepreneurial outcome. Considering that institutional transformation may happen both in host and home environment, comprehensive research on the role of the changes in home and host institutions in influencing EO in business group is an interesting research opportunity. Further, institutional change may facilitate or stifle EO in the affiliated firm, which can be another area of further investigation (Stucchi et al., 2015). Third, our usage of the degree of internationalization (combination of foreign sales, foreign assets, and overseas subsidiaries) creates another limitation in our study as the degree of internationalization is only one aspect of expansion into host locations. We know little about whether aggressive internationalization helps to develop EO in the affiliated firms (Kumar et al., 2020). We also do not know the entrepreneurial implications of the foreign market entry mode or simultaneous expansion into multiple international locations for the affiliated firms (Laufs \& Schwens, 2014; Lebedev, Peng, Xie, \& Stevens, 2015). Therefore, further research on various facets of internationalization (e.g. speed, spread, and entry mode) will be a logical extension of the present inquiry (Hitt, Li, \& Xu, 2016; Kumar et al., 2020).

\section{Conclusion}

In conclusion, economic and social significance of business groups are continuing to grow (Chittoor et al., 2015) while entrepreneurial behavior in business groups has become a critical strategic behavior in hyper competitive international (Kumar et al., 2012) and domestic markets (Manikandan \& Ramachandran, 2015). This study looks beyond advantages of affiliation to business group (Ghemawat \& Khanna, 1998; Zhu \& Chung, 2014) and argues that business group affiliation will reduce EO in affiliated firms. We also find that the negative influence of business group affiliation can be alleviated - possibly, even countered-through international expansion due to overseas competition, and when associated with a poorly performing affiliated firm, due to increasing domestic competition. These are key findings in the domain of strategic management literature that can help business group affiliated firms in emerging economies in making a choice between alternative strategic options (Carney et al., 2011).

Funding Open Access funding enabled and organized by CAUL and its Member Institutions. 
Open Access This article is licensed under a Creative Commons Attribution 4.0 International License, which permits use, sharing, adaptation, distribution and reproduction in any medium or format, as long as you give appropriate credit to the original author(s) and the source, provide a link to the Creative Commons licence, and indicate if changes were made. The images or other third party material in this article are included in the article's Creative Commons licence, unless indicated otherwise in a credit line to the material. If material is not included in the article's Creative Commons licence and your intended use is not permitted by statutory regulation or exceeds the permitted use, you will need to obtain permission directly from the copyright holder. To view a copy of this licence, visit http://creativecommons.org/licen ses/by/4.0/.

\section{References}

Aguilera, R. V., \& Crespi-Cladera, R. (2016). Global corporate governance: On the relevance of firms' ownership structure. Journal of World Business, 51(1), 50-57.

Ahluwalia, M. S. (2002). Economic reforms in India since 1991: Has gradualism worked? The Journal of Economic Perspectives, 16(3), 67-88.

Ahuja, G. (2000). Collaboration networks structural holes and innovation: A longitudinal study. Administrative Science Quarterly, 45(3), 425-455.

Ahuja, G., \& Morris Lampert, C. (2001). Entrepreneurship in the large corporation: A longitudinal study of how established firms create breakthrough inventions. Strategic Management Journal, 22(6-7), 521-543.

Atuahene-Gima, K., \& Ko, A. (2001). An empirical investigation of the effect of market orientation and entrepreneurship orientation alignment on product innovation. Organization Science, 12(1), 54-74.

Ayyagari, M., Dau, L. A., \& Spencer, J. (2015). Strategic responses to FDI in emerging markets: Are core members more responsive than peripheral members of business groups? Academy of Management Journal, 58(6), 1869-1894.

Bae, K.-H., Kang, J.-K., \& Kim, J.-M. (2002). Tunneling or value added? Evidence from mergers by Korean business groups. The Journal of Finance, 57(6), 2695-2740.

Baltagi, B. (2005). Econometric analysis of panel data. John Wiley \& Sons.

Bansal, P., \& Clelland, I. (2004). Talking trash: Legitimacy, impression management, and unsystematic risk in the context of the natural environment. Academy of Management Journal, 47(1), 93-103.

Barney, J. (1991). Firm resources and sustained competitive advantage. Journal of Management, 17(1), 99-120.

Bartlett, C. A., \& Ghoshal, S. (1988). Organizing for worldwide effectiveness: The transnational solution. California Management Review, 31(1), 54-74.

Belenzon, S., \& Berkovitz, T. (2010). Innovation in business groups. Management Science, 56(3), 519-535.

Bertrand, M., Mehta, P., \& Mullainathan, S. (2002). Ferreting out tunneling: An application to Indian business groups. The Quarterly Journal of Economics, 117(1), 121-148.

Bhaumik, S. K., Estrin, S., \& Mickiewicz, T. (2017). Ownership identity, strategy and performance: Business group affiliates versus independent firms in India. Asia Pacific Journal of Management, 34, 281-311.

Bruton, G. D., Filatotchev, I., Si, S., \& Wright, M. (2013). Entrepreneurship and strategy in emerging economies. Strategic Entrepreneurship Journal, 7(3), 169-180.

Bucheli, M., Salvaj, E., \& Kim, M. (2019). Better together: How multinationals come together with business groups in times of economic and political transitions. Global Strategy Journal, 9(2), 176-207. https://doi.org/10.1002/gsj.1326

Carney, M., Gedajlovic, E. R., Heugens, P. P. M. A. R., Van Essen, M., \& Van Oosterhout, J. H. (2011). Business group affiliation performance context and strategy: A meta-analysis. Academy of Management Journal, 54(3), 437-460.

Carney, M., Van Essen, M., Estrin, S., \& Shapiro, D. (2018). Business Groups reconsidered: Beyond paragons and parasites. Academy of Management Perspectives, 32(4), 493-516.

Castellacci, F. (2015). Institutional voids or organizational resilience? Business groups innovation and market development in Latin America. World Development, 70, 43-58. 
Chacar, A., \& Vissa, B. (2005). Are emerging economies less efficient? Performance persistence and the impact of business group affiliation. Strategic Management Journal, 26(10), 933-946.

Chakrabarti, R., Megginson, W., \& Yadav, P. K. (2008). Corporate governance in India. Journal of Applied Corporate Finance, 20(1), 59-72.

Chang, S. J., \& Hong, J. (2000). Economic performance of group-affiliated companies in Korea: Intragroup resource sharing and internal business transactions. Academy of Management Journal, 43(3), 429-448.

Chang, S.-J., Chung, C.-N., \& Mahmood, I. P. (2006). When and how does business group affiliation promote firm innovation? A tale of two emerging economies. Organization Science, 17(5), 637-656.

Chari, M. D. (2013). Business groups and foreign direct investments by developing country firms: An empirical test in India. Journal of World Business, 48(3), 349-359.

Chittoor, R., \& Aulakh, P. S. (2015). Organizational landscape in India: Historical development, multiplicity of forms and implications for practice and research. Long Range Planning, 48(5), 291-300.

Chittoor, R., Kale, P., \& Puranam, P. (2015). Business groups in developing capital markets: Towards a complementarity perspective. Strategic Management Journal, 36(9), 1277-1296.

Chittoor, R., Sarkar, M., Ray, S., \& Aulakh, P. S. (2009). Third-world copycats to emerging multinationals: Institutional changes and organizational transformation in the Indian pharmaceutical industry. Organization Science, 20(1), 187-205.

Choi, S. B., Lee, S. H., \& Williams, C. (2011). Ownership and firm innovation in a transition economy: Evidence from China. Research Policy, 40(3), 441-452.

Colpan, A. M., Hikino, T., \& Lincoln, J. R. (2010). Introduction. In A. M. Colpan, T. Hikino, \& J. R. Lincoln (Eds.), The Oxford handbook of business groups (pp. 1-14). Oxford University Press.

Contractor, F. J., Kumar, V., \& Dhanaraj, C. (2015). Leveraging India: Global interconnectedness and locational competitive advantage. Management International Review, 55(2), 159-179.

Covin, J., \& Miles, M. (2006). Corporate entrepreneurship and the pursuit of competitive advantage. Entrepreneurship Theory \& Practice, 23(3), 47-63.

Covin, J., \& Slevin, D. P. (1989). Strategic management of small firms in hostile and benign environments. Strategic Management Journal, 10(1), 75-87.

Covin, J., \& Slevin, D. P. (1991). A conceptual model of entrepreneurship as firm behavior. Entrepreneurship Theory and Practice, 16(1), 7-25.

Covin, J., \& Wales, W. (2012). The measurement of entrepreneurial orientation. Entrepreneurship Theory and Practice, 36(4), 677-702.

Damantopoulos, A., \& Winklhofer, H. M. (2001). Index construction with formative indicators: An alternative to scale development. Journal of Marketing Research, 38(2), 269-277.

Elango, B., \& Pattnaik, C. (2007). Building capabilities for international operations through networks: A study of Indian firms. Journal of International Business Studies, 38(4), 541-555.

Feenstra, R. C., Hamilton, G. G., \& Lim, E. M. (2002). Chaebol and catastrophe: A new view of the Korean business groups and their role in the financial crisis. Asian Economic Papers, 1(2), 1-45.

Gaur, A., \& Delios, A. (2015). International diversification of emerging market firms: The role of ownership structure and group affiliation. Management International Review, 55(2), 235-253.

Gaur, A., \& Kumar, V. (2009). International diversification, business group affiliation and firm performance: Empirical evidence from India. British Journal of Management, 20(2), 172-186.

Gaur, A. S., Kumar, V., \& Sarathy, R. (2011). Liability of foreignness and internationalization of emerging market firms. In C. G. Asmussen, T. Pedersen, T. M. Devinney, \& L. Tihanyi (Eds.), Advances in International Management (Vol. 24, pp. 211-233). Emerald Group Publishing Limited.

Ghemawat, P., \& Khanna, T. (1998). The nature of diversified business groups: A research design and two case studies. The Journal of Industrial Economics, 46(1), 35-61.

Gopal, S., Manikandan, K. S., \& Ramachandran, J. (2021). Are There Limits to Diversification in Emerging Economies? Distinguishing between Firm-Level and Business Group Strategies. Journal of Management Studies, 58(6), 1532-1568. https://doi.org/10.1111/joms.12680

Gubbi, S., Aulakh, P. S., \& Ray, S. (2015). International search behavior of business group affiliated firms: Scope of institutional changes and intragroup heterogeniety. Organization Science, 26(5), 1485-1501.

Gulati, R., Nohria, N., \& Zaheer, A. (2000). Strategic networks. Strategic Management Journal, 21(3), 203-215.

Gupta, V. K., \& Batra, S. (2015). Entrepreneurial orientation and firm performance in Indian SMEs: Universal and contingency perspectives. International Small Business Journal. https://doi.org/10. $1177 / 0266242615577708$ 
Hair, J. F., Tatham, R. L., Anderson, R. E., \& Black, W. (2006). Multivariate data analysis (Vol. 6). Pearson Prentice Hall Upper Saddle River.

Hill, C. W. (1995). National institutional structures, transaction cost economizing and competitive advantage: The case of Japan. Organization Science, 6(1), 119-131.

Hillman, A. J., Withers, M. C., \& Collins, B. J. (2009). Resource Dependence Theory: A Review. Journal of Management, 35(6), 1404-1427.

Hitt, M. A., Hoskisson, R. E., \& Kim, H. (1997). International diversification: Effects on innovation and firm performance in product-diversified firms. Academy of Management Journal, 40(4), 767-798.

Hitt, M. A., Li, D., \& Xu, K. (2016). International strategy: From local to global and beyond. Journal of World Business, 51(1), 58-73.

Holmes, R. M., Hoskisson, R. E., Kim, H., Wan, W. P., \& Holcomb, T. R. (2018). International strategy and business groups: A review and future research agenda. Journal of World Business, 53(2), 134-150. https://doi.org/10.1016/j.jwb.2016.11.003

Ireland, R. D., Covin, J., \& Kuratko, D. F. (2009). Conceptualizing corporate entrepreneurship strategy. Entrepreneurship Theory and Practice, 33(1), 19-46.

Jia, N., Shi, J., \& Wang, Y. (2013). Coinsurance within business groups: Evidence from related party transactions in an emerging market. Management Science, 59(10), 2295-2313.

Joe, D. Y., \& Oh, F. D. (2017). Spillover effects within business groups: The case of Korean chaebols. Management Science, 64(3), 1396-1412.

Johanson, J., \& Vahlne, J.-E. (2009). The Uppsala internationalization process model revisited: From liability of foreignness to liability of outsidership. Journal of International Business Studies, 40(9), 1411-1431.

Joshi, A. M., \& Nerkar, A. (2011). When do strategic alliances inhibit innovation by firms? Evidence from patent pools in the global optical disc industry. Strategic Management Journal, 32(11), 1139-1160.

Kant, K. (2017). M-Cap of top 10 business groups up 46\% in 2017. Business-Standard. https:// www.business-standard.com/article/markets/m-cap-of-top-10-business-groups-up-46-in-2017117123100005_1.html. Accessed 6 Feb 2022

Karuna, C. (2007). Industry product market competition and managerial incentives. Journal of Accounting and Economics, 43(2-3), 275-297.

Kedia, B. L., Mukherjee, D., \& Lahiri, S. (2006). Indian business groups: Evolution and transformation. Asia Pacific Journal of Management, 23(4), 559-577.

Kennedy, P. (1998). A guide to econometrics. MIT Press.

Khanna, T., \& Palepu, K. (1997). Why focused strategies may be wrong for emerging markets. Harvard Business Review, 75(4), 41-51.

Khanna, T., \& Palepu, K. (2000). Is group affiliation profitable in emerging markets? An analysis of diversified Indian business groups. The Journal of Finance, 55(2), 867-891.

Khanna, T., \& Rivkin, J. W. (2001). Estimating the performance effects of business groups in emerging markets. Strategic Management Journal, 22(1), 45-74.

Khanna, T., \& Yafeh, Y. (2007). Business groups in emerging markets: Paragons or parasites? Journal of Economic Literature, 45(2), 331-372.

Kim, H., Hoskisson, R. E., Tihanyi, L., \& Hong, J. (2004). The evolution and restructuring of diversified business groups in emerging markets: The lessons from chaebols in Korea. Asia Pacific Journal of Management, 21(1-2), 25-48.

Kim, H., \& Song, J. (2017). Filling institutional voids in emerging economies: The impact of capital market development and business groups on M\&A deal abandonment. Journal of International Business Studies, 48(3), 308-323.

Kostova, T., Roth, K., \& Dacin, M. T. (2008). Institutional theory in the study of multinational corporations: A critique and new directions. Academy of Management Review, 33(4), 994-1006.

Kumar, V., Gaur, A. S., \& Pattnaik, C. (2012). Product diversification and international expansion of business groups. Management International Review, 52(2), 175-192.

Kumar, V., Singh, D., Purkayastha, A., Popli, M., \& Gaur, A. (2020). Springboard internationalization venturing by emerging market firms: Speed of first cross-border acquisition. Journal of International Business Studies, 51(2), 172-193. https://doi.org/10.1057/s41267-019-00266-0

Kuratko, D. F. (2007). Corporate Entrepreneurship. Now Publishers Inc.

Lamin, A. (2006). The effect of business group affiliation on firm market and international strategies Unpublished Dissertation. Carlson School of Management University of Minnesota. 
Lamin, A. (2013). Business Groups as Information Resource: An Investigation of Business Group Affiliation in the Indian Software Services Industry. Academy of Management Journal, 56(5), 1487-1509.

Laufs, K., \& Schwens, C. (2014). Foreign market entry mode choice of small and medium-sized enterprises: A systematic review and future research agenda. International Business Review, 23(6), 1109-1126.

Lebedev, S., Peng, M. W., Xie, E., \& Stevens, C. E. (2015). Mergers and acquisitions in and out of emerging economies. Journal of World Business, 50(4), 651-662.

Li, S., \& Yayavaram, S. (2021). Attenuating the negative effects of network change on innovation: A whole network level analysis of Taiwanese business groups. Asia Pacific Journal of Management, 38, 151-177.

Lu, J. W., \& Beamish, P. W. (2001). The internationalization and performance of SMEs. Strategic Management Journal, 22(6-7), 565-586.

Lyon, D. W., Lumpkin, G. T., \& Dess, G. G. (2000). Enhancing entrepreneurial orientation research: Operationalizing and measuring a key strategic decision making process. Journal of Management, 26(5), 1055-1085.

Madhok, A., \& Keyhani, M. (2012). Acquisitions as entrepreneurship: Asymmetries opportunities and the internationalization of multinationals from emerging economies. Global Strategy Journal, 2(1), 26-40.

Mahmood, I. P., \& Mitchell, W. (2004). Two faces: Effects of business groups on innovation in emerging economies. Management Science, 50(10), 1348-1365.

Mahmood, I. P., Zhu, H., \& Zaheer, A. (2017). Centralization of intragroup equity ties and performance of business group affiliates. Strategic Management Journal, 38(5), 1082-1100.

Mahmood, I. P., Zhu, H., \& Zajac, E. J. (2011). Where can capabilities come from? Network ties and capability acquisition in business groups. Strategic Management Journal, 32(8), 820-848.

Manikandan, K. S., \& Ramachandran, J. (2015). Beyond institutional voids: Business groups incomplete markets and organizational form. Strategic Management Journal, 36(4), 598-617.

Masulis, R. W., Pham, P. K., \& Zein, J. (2011). Family business groups around the world: Financing advantages control motivations and organizational choices. The Review of Financial Studies, 24(11), 3556-3600.

Miller, D. (1983). The correlates of entrepreneurship in three types of firms. Management Science, 29(7), 770-791.

Miller, D., \& Breton-Miller, L. (2011). Governance social identity and entrepreneurial orientation in closely held public companies. Entrepreneurship Theory and Practice, 35(5), 1051-1076.

Morck, R., Wolfenzon, D., \& Yeung, B. (2005). Corporate governance economic entrenchment and growth. Journal of Economic Literature, 43(3), 655-720.

Morck, R., \& Yeung, B. (2003). Agency problems in large family business groups. Entrepreneurship Theory and Practice, 27(4), 367-382.

Mukherjee, D., Makarius, E. E., \& Stevens, C. E. (2018). Business group reputation and affiliates' internationalization strategies. Journal of World Business, 53(2), 93-103.

Mukherjee, D., Makarius, E. E., \& Stevens, C. E. (2021). A reputation transfer perspective on the internationalization of emerging market firms. Journal of Business Research, 123, 568-579.

Nakajima, K., \& Sasaki, T. (2020). Business group affiliation, corporate diversification, and cash holdings. Asia Pacific Journal of Management. https://doi.org/10.1007/s10490-020-09720-2

Nuruzzaman, N., Singh, D., \& Pattnaik, C. (2019). Competing to be innovative: Foreign competition and imitative innovation of emerging economy firms. International Business Review, 28(5), 101490.

Palepu, K. (1985). Diversification strategy profit performance and the entropy measure. Strategic Management Journal, 6(3), 239-255.

Pattnaik, C., Lu, Q., \& Gaur, A. S. (2018). Group affiliation and entry barriers: The dark side of business groups in emerging markets. Journal of Business Ethics, 153, 1051-1066. https://doi.org/10.1007/ s10551-018-3914-2

Pedersen, T., \& Stucchi, T. (2014). Business groupsinstitutional transition and the internationalization of firms from emergingeconomies. In A. Cuervo-Cazurra \& R. Ramamurti (Eds.), Understanding Multinationals from Emerging Markets. Cambridge: Cambridge Univ Press.

Peng, M. W., \& Delios, A. (2006). What determines the scope of the firm over time and around the world? An Asia Pacific perspective. Asia Pacific Journal of Management, 23(4), 385-405.

Peng, M. W., Wang, D. Y., \& Jiang, Y. (2008). An institution-based view of international business strategy: A focus on emerging economies. Journal of International Business Studies, 39(5), 920-936. 
Pfeffer, J., \& Salancik, G. R. (1978). The external control of organizations: A resource dependence perspective. Harper \& Row.

Piperopoulos, P., Wu, J., \& Wang, C. (2018). Outward FDI, location choices and innovation performance of emerging market enterprises. Research Policy, 47(1), 232-240.

Purkayastha, A. (2018). Performance of business group affiliated firms in emerging markets: Causal mediation analysis of internationalization and investment into innovation strategy. International Journal of Emerging Markets, 13(6), 1538-1558.

Purkayastha, A., Kumar, V., \& Gupta, V. K. (2021a). Emerging market internationalizing firms: Learning through internationalization to achieve entrepreneurial orientation. Journal of World Business, 56(5), 101207. https://doi.org/10.1016/j.jwb.2021.101207

Purkayastha, A., Pattnaik, C., \& Pathak, A. A. (2021b). Agency conflict in diversified business groups and performance of affiliated firms in India: Contingent effect of external constraint and internal governance. European Management Journal. https://doi.org/10.1016/j.emj.2021.05.004

Purkayastha, S., Kumar, V., \& Lu, J. W. (2017). Business group heterogeneity and the internationalizationperformance relationship: Evidence from Indian business groups. Asia Pacific Journal of Management, 34(2), 247-279.

Purkayastha, S., Veliyath, R., \& George, R. (2019). The roles of family ownership and family management in the governance of agency conflicts. Journal of Business Research, 98, 50-64.

Ramachandran, J., Manikandan, K. S., \& Pant, A. (2013). Why conglomerates thrive (outside the US). Harvard Business Review, 91(12), 110-119.

Ramaswamy, K., Li, M., \& Petitt, B. S. (2012). Why do business groups continue to matter? A study of market failure and performance among Indian manufacturers. Asia Pacific Journal of Management, 29(3), 643-658.

Ramaswamy, K., Purkayastha, S., \& Petitt, B. S. (2017). How do institutional transitions impact the efficacy of related and unrelated diversification strategies used by business groups? Journal of Business Research, 72, 1-13.

Ren, C. R., \& Guo, C. (2011). Middle managers' strategic role in the corporate entrepreneurial process: Attention-based effects. Journal of Management, 37(6), 1586-1610.

Rugman, A. M. (1976). Risk reduction by international diversification. Journal of International Business Studies, 7(2), 75-80.

Sauerwald, S., Heugens, P. P., Turturea, R., \& Van Essen, M. (2019). Are all private benefits of control ineffective? Principal-Principal benefits external governance quality and firm performance. Journal of Management Studies, 56(4), 725-757.

Scott, M., \& Bruce, R. (1987). Five stages of growth in small business. Long Range Planning, 20(3), 45-52.

Shin, J., Mendoza, X., \& Choi, C. (2021). Do internationalizing business group affiliates perform better after promarket reforms? Evidence from Korean SMEs. Asia Pacific Journal of Management. https://doi.org/10.1007/s10490-021-09751-3

Siegel, J., \& Choudhury, P. (2012). A reexamination of tunneling and business groups: New data and new methods. Review of Financial Studies, 25(6), 1763-1798.

Singla, C., \& George, R. (2013). Internationalization and performance: A contextual analysis of Indian firms. Journal of Business Research, 66(12), 2500-2506.

Stam, W., \& Elfring, T. (2008). Entrepreneurial orientation and new venture performance: The moderating role of intra and extra industry social capital. Academy of Management Journal, 51(1), 97-111.

Stock, J., \& Yogo, M. (2005). Asymptotic Distributions of Instrumental Variables Statistics with Many Instruments. In D. W. K. Andrews \& J. H. Stock (Eds.), Identification and Inference for Econometric Models (pp. 109-120). Cambridge University Press.

Stoll, J. D. (2015). India's Mahindra enters racing, but with eye on Tesla. The Wall Street Journal. http:// www.wsj.com/articles/indias-mahindra-enters-racing-but-with-eye-on-tesla-1426623392. Accessed 6 Feb 2022

Stucchi, T., Pedersen, T., \& Kumar, V. (2015). The effect of institutional evolution on Indian firms' internationalization: Disentangling inward-and outward-oriented effects. Long Range Planning, 48(5), $346-359$.

Teece, D. J. (2014). A dynamic capabilities-based entrepreneurial theory of the multinational enterprise. Journal of International Business Studies, 45(1), 8-37.

Thakur-Wernz, P., Cantwell, J., \& Samant, S. (2019). Impact of international entry choices on the nature and type of innovation: Evidence from emerging economy firms from the Indian bio-pharmaceutical industry. International Business Review, 28(6), 101601. 
Wailerdsak, N., \& Suehiro, A. (2010). Business groups in Thailand. In A. M. Colpan, Hikino, Takashi, \& J. R. Lincoln (Eds.), The Oxford handbook of business groups. Oxford: Oxford University Press.

Wan, W. P., \& Hoskisson, R. E. (2003). Home country environments corporate diversification strategies and firm performance. Academy of Management Journal, 46(1), 27-45.

Wang, C., Yi, J., Kafouros, M., \& Yan, Y. (2015). Under what institutional conditions do business groups enhance innovation performance? Journal of Business Research, 68(3), 694-702.

Wooldridge, J. (2012). Introductory econometrics: A modern approach. Cengage Learning.

Yiu, D., Bruton, G. D., \& Lu, Y. (2005). Understanding business group performance in an emerging economy: Acquiring resources and capabilities in order to prosper. Journal of Management Studies, 42(1), 183-206.

Young, M. N., Peng, M. W., Ahlstrom, D., Bruton, G. D., \& Jiang, Y. (2008). Corporate governance in emerging economies: A review of the principal-principal perspective. Journal of Management Studies, 45(1), 196-220.

Yung Sil, Y. (2017). Top 4 Conglomerates Take up $60 \%$ of Korean Stock Market Cap Increase. BusinessKorea. http://www.businesskorea.co.kr/. Accessed 6 Feb 2022

Zhu, H., \& Chung, C.-N. (2014). Portfolios of Political Ties and Business Group Strategy in Emerging Economies Evidence from Taiwan. Administrative Science Quarterly, 59(4), 599-638.

Publisher's Note Springer Nature remains neutral with regard to jurisdictional claims in published maps and institutional affiliations.

Anish Purkayastha (PhD, Indian Institute of Management, Ahmedabad) is Lecturer in Discipline of International Business, at the University of Sydney Business School. His academic papers are published in Journal of International Business Studies, Journal of World Business and Journal of Business Research. Anish's research interests are Global Strategy, Behavioral Strategy, Emerging Markets, and Business Group. His teaching areas are International Business, Strategic Management, and Managerial Cognition.

Vishal K. Gupta (PhD, University of Missouri) is Professor of management at The University of Alabama. His research interests are in the areas of entrepreneurial orientation, gender in management, and international business. He has authored more than seventy-five research papers and received numerous awards for his research. Before embarking on an academic career, he worked full-time in the family enterprise. $\mathrm{He}$ is the author of the textbook 'Small Business: Creating Value Through Entrepreneurship' published by Wiley (2021). 